Article

\title{
Approaching Impersonal Life with Clarice Lispector
}

\author{
Fernanda Negrete
}

Department of Romance Languages and Literatures, The State University of New York at Buffalo, Buffalo, NY 14260-4620, USA; fnegrete@buffalo.edu

Received: 9 March 2018; Accepted: 25 May 2018; Published: 31 May 2018

\begin{abstract}
Clarice Lispector's concern with writing life beyond the limits of identity and representation leads her to posit the univocity of being in a series of surprising corporeal and linguistic gestures to reveal a fundamental shift in time. I explore the convergence between this project in Lispector and both major and minor terms in the philosophy of Gilles Deleuze (from "encounter" and "immanence" to "savage" and "birth"), shedding light on some fundamental aspects of the latter's transcendental empiricism. Furthermore, focusing especially on the 1973 fiction Água Viva, I show that Lispector's work insists on impersonal life's relational condition, which extends to the creation of an original reader-writer relationship, through a mode of receptivity beyond meaning in which feminine and natal approaches are crucial.
\end{abstract}

Keywords: Lispector; Deleuze; life; impersonal; univocity; immanence; sauvage; cry; time; birth; feminine; relation; language; reading; writing; Água Viva

\section{From "my life" to "inhuman life"}

Until now I had called life my sensitivity to life. But being alive is something else.

Being alive is a thick radiant indifference. Being alive is unattainable by the finest sensitivity. Being alive is inhuman-the deepest meditation is so empty that a smile exhales as from a matter. ${ }^{1}$ (Lispector 1964, p. 171)

The writer of these sentences in Clarice Lispector's A paixão Segundo G.H. (The Passion According to G.H.) begins her text in the wake of a catastrophe: "Yesterday however I lost my human montage for hours and hours" "Ontem no entanto perdi durante horas e horas a minha montagem humana" (p. 12). The "human montage" or particular "sensibility to life" in question for G.H., now reduced to the letters on her typewriter's two central keys, had been that of a bourgeois woman in Rio de Janeiro until now, as the citation that begins this essay states, "ate agora." This now marks a complete disruption of time, upon the nameless woman's encounter with an old cockroach living in her apartment's recently vacated servant's quarters. She is divested from what enables speaking beings to speak of life with possessive pronouns, to call life "mine," and this not only introduces a distinction between "my sensibility to life" and a "being alive" unclothed by a sense of property and propriety; ${ }^{2}$ it also opens up the possibility of something entirely different, "outra coisa" "something else" as life, "a thick radiant indifference" whose nature, the writer admits, is outright inhuman.

1 All translations are my own, unless otherwise noted. In making my translations from Lispector's idiosyncratic Portuguese to highlight conceptual possibilities of her phrases related to my argument, I have also consulted the recent Penguin Modern Classics English translations of the corresponding works.

2 G.H.'s first close look at the cockroach she has impulsively smashed with a wardrobe door leads her to think of the Biblical prohibition against unclean animals and to state: "I had committed the forbidden act of touching the impure" (pp. 71-72). The cockroach raises the matters of property, propriety, and purity together. 
Lispector's novels consistently delve into the problem of the univocity of being. ${ }^{3}$ In The Passion it is a matter of disclosing this univocity in the encounter between woman and cockroach, but her first novel from 1944 (Lispector 1963) already highlights this aspect of Spinoza's thought, in a quote transcribed by the character Otávio: "In the office he would place, high up, Spinoza in translation: 'Bodies distinguish themselves from each other in relation to movement and rest, to speed and slowness and not in relation to substance'" (Lispector 1963, p. 109). Exploring the univocity of being enables a subtly different perspective from that of the "human montage," which consists in a sense of self whose oppositional relation to objects in a world determines the order of time and subjects everything to meaning. The shift at stake in Lispector entails a critique of such habits of thought and a correlative experimental writing at the limits of language. Lispector did not follow any particular philosopher in producing her fiction. ${ }^{4}$ While modernist literature played a crucial role in the philosophy of Gilles Deleuze (whose transcendental empiricism is crucial for the present essay), he, for his part, never mentioned Lispector's texts. ${ }^{5}$ Yet the questions and approaches each one explored have striking points of convergence, regarding life and time, that I want to highlight in this essay, which situates the place of writing and reading for Lispector on a plane of immanence with life and time. This plane of life beyond the "human montage" involves a very specific logic, whose nature, I show, is fundamentally relational, although it is a rare relation that requires boundaries between self and other to dissolve. I locate the stakes of this relation in a set of peculiar gestures in Lispector's works: cannibalism, handholding between writer and reader, breastfeeding, the cry ("grito") and its associated register of birth/birthing. By engaging with these gestures that emphasize the univocity of being I propose that the feminine and natal mode of reading and writing beyond knowledge and meaning in Lispector constitutes the time of the event that Lispector and Deleuze designate as impersonal life. ${ }^{6}$

Relation after the unbinding of self in Lispector, which exposes writing and naming life to the limits of language, is connected to overcoming an active-passive dialectic, in favor of a receptive contemplation that Lispector strives to formulate, in terms such as "beatitude" and in deliberately ungrammatical phrases. Yet this beatitude, which both Lispector and Deleuze envision, is complicated by the violence of the encounter that triggers a shift out of the human montage for both writers, who underscore this shift in terms of something "savage," ${ }^{77}$ so let us first look at these notions.

3 Duns Scotus, who proposed the theory in the thirteenth century, considers that the difference between God and beings is merely of degree; in The Passion, the cockroach's degree of life is greater than the woman's, as a passage, cited below, makes evident. This essay embraces Gilles Deleuze's creative link between Scotus and Baruch Spinoza's immanent cause. In his introduction to the recent English translation of The Passion, Caetano Veloso, recalling a friend from young adulthood who disliked the novel's "pantheism," considers instead "the possibility that Spinoza wrote his Ethics in Portuguese" (Veloso 2014, p. ix). He implies that the thought that allows for the equation of God and nature must be intimately linked to Spinoza's mother tongue.

4 For a list of modernist writers and philosophers she read, see (Jiménez Quenguan 2009). Her last, posthumously published novel, Um sopro de vida, features an epigraph from Nietzsche. Elizabeth Bishop, who met Lispector and translated some of her stories, remarks on the absence of discernable literary influences as well: "she's the most non-literary writer I've ever known... She's never read anything that I can discover-I think she's a 'self-taught' writer, like a primitive painter" in (Lispector 2011, p. viii).

5 Both authors, however, interacted with Pierre de Lescure, founding editor of Les Éditions de Minuit, which says something about their political and speculative affinities. The Lispector archive at Casa de Rui Barbosa contains correspondence with de Lescure between 1951 and 1961.

6 A discussion of immanence in connection with the feminine (in Irigaray) and the politics of literature in Lispector's A Hora da Estrela is discussed in "Figurations of Immanence: Writing the Subaltern \& the Feminine in Clarice Lispector" (Shellhorse 2017).

7 A discussion on violence versus care in Lispector's work has developed among critics over the years. Hélène Cixous' interpretation of Lispector, to which the latter's recognition in non-Latin American criticism is due, emphasizes a feminine and maternal ethics of care for the other (Cixous 1989; Cixous 1990), whereas Marta Peixoto contests this and develops a notion of "textual violence" by recalling the importance of violence in Lispector's narratives (Peixoto 1994). Irving Goh has recently pointed out the transgressive role of touch in Lispector, which extends to eating the other (Goh 2016a). 


\section{Beatitude}

"A life" was the succinct definition of immanence Deleuze proposed in the very last text he published in his lifetime ${ }^{8}$ (Deleuze 2007). He elsewhere discusses literature as a practice at the service of Life, "beyond the matter of any livable or lived experience" (Deleuze 1997, p. 1), so it is no surprise that the most accurate picture he can find of what he means by "a life" comes from a work of literature: "No one has described what a life is better than Charles Dickens, when he takes the indefinite article as an index of the transcendental" (Deleuze 2007, p. 386). In the novel Our Mutual Friend, a distinction emerges between a man's individual life (a mean, unlikable one in this case) and "an impersonal and singular life" that has "a kind of beatitude" (p. 387) of its own and that only becomes accessible in the novel when the man falls into a coma. Clarice Lispector was more than finely attuned to the distinction Deleuze notices in Dickens' novel, between an individual, personal life, on the one hand, and the immanent, impersonal beatitude of a life, on the other; the latter approach to life is the central element of Lispector's writing across the decades, and I would even venture, to echo Deleuze's rhetoric, that no one has developed a more sustained, close encounter with this immanent life in writing than Lispector. It is as if the "loss of human montage" described in The Passion had decisively engaged her on this "inhuman" path of immanent life, featuring states of "grace" or "beatitude" to which she had brought, if only momentarily, her characters since the early novels. ${ }^{9}$ Whereas in her other novels a character and situation mediate the field of life, which opens up as a strange experience at the limits of language (for example, G.H. has an encounter with a cockroach), in her 1973 Água Viva a direct encounter with life is what mobilizes the anonymous writing voice throughout the text. ${ }^{10}$ Since the voice attends to this unpredictable, uncontrollable movement of life as such, introducing and sustaining the adventures of any characters would in this case narrow the scope and flow. Água Viva attains a treatment of the "I" as a voice for "the mystery of the impersonal that is the "it" (Lispector 1973, p. 28). In English within the original Portuguese text, the inhuman third-person singular pronoun it reappears throughout Lispector's most radical experiment of writing a direct encounter with life, just as Deleuze, sharing this very concern, investigates an impersonal third- and fourth-person singular (on, ça, and il in French): "the on (one) of the pure event wherein one/it dies in the same way as it rains (il meurt comme il pleut). The splendor of the on is the splendor of the event itself or of the fourth person" (Deleuze 1990, p. 178 modified). The pronoun it names the immanent transcendental in Água viva, as we will see. The cockroach's inhuman "thick, radiant indifference" in The Passion becomes even more formless in Água Viva, a fiction (as the author designated it) composed by careful stitching together of small fragments produced at widely disparate moments. The result is neither a Dada poem nor a linear cohesive account of any situation except the very passing of instants, unmediated by characters or situations: "What shall I tell you? I shall tell you the instants" (Lispector 1973, p. 20). ${ }^{11}$ As an impersonal sensibility for life, the "radiant indifference" in play is thus the contrary of the inattention to difference that instead enables the concerns of the human montage.

8 This was only two months before his suicide. There are several readings of this act in relation to Deleuze's central philosophical problem of immanent life. See, for instance, Osaki (2008) and Beaubatie (2000).

9 These moments of "beatitude" or "grace" occur unexpectedly when the characters dwell in quiet solitude. Interestingly, before The Passion, her novels are narrated in the third person, whereas The Passion and Água Viva use the first person and are at once the most radical in the quest beyond human self-identity. Uma Aprendizagem ou O Livro dos Prazeres (Lispector 1969) appears in between these two works. While it returns to the third person, its narrator immediately enters into free indirect discourse to describe the most intimate, wordless bodily experiences in its female protagonist, Lori, such that she appears detached too from a "human montage." She is, after all, named after a Nordic siren (Lorelei). Appropriately, her lover in the novel is Ulysses.

10 The two novels after Agua viva return to characters attempting a different experiment; there seems to be a concern with exposing the very process of approaching and giving life to a character, and of inhabiting the virtual dimension of writing, as I will show. Shellhorse (2017) reads The Hour of the Star as Lispector's most radical experiment, especially regarding the Latin American political and literary context.

11 Distinct figures such as a man, a flower, a mother cat, a glass of water, a mirror, a closet, or a Saturday do emerge, like reflections in the water, along Água Viva's phrases, but the presence of such images is momentary, and they are effortlessly left behind as the text continues to attend to the rigor of boundless life. Plot is, for the same reason, also nonexistent. 
A strong resonance with Deleuze's thought about beatitude appears in the following passage from Água Viva, which the narrator entitles "À margem da beatitude" "On the margin of beatitude": True thought seems to have no author.

And beatitude has that same trait. Beatitude begins in the moment when the act of thinking has freed itself from the necessity of form. Beatitude begins at the moment when the thinking-feeling has surpassed the author's need to think- $\mathrm{he}^{12}$ no longer needs to think and now finds himself close to the grandeur of the nothing. (Lispector 1973, p. 82)

Beatitude is thus an experience of impersonal, formless thought, and it brings the thinker or author of the thought close to "the grandeur of the nothing" insofar it unbinds from the form of self and from any quantity or quality. ${ }^{13}$ Água Viva here insists on a grandeur or radiance of thought's emptiness that G.H.'s meditation of inhuman life had introduced: "so empty that a smile exhales as from a matter." This delicate emanation, also described by G.H. as "the radiant center of a neuter love in Hertz waves" (Lispector 1964, p. 171) is the splendor of beatitude.

Deleuze ascribed a field (transcendental) and a plane (immanence) to the mystery of impersonal thought where a life emerges. These elements structure his transcendental empiricism, which neither confines itself to the limits of experience, nor posits transcendence, which requires a subject and object in order to exceed immediate experience. ${ }^{14}$ Instead, sensation and the virtual meet without the intermediaries of a subject or its representations, giving rise instead to what he had earlier called "thought without image" (Deleuze 1994) since images of thought mirror and perpetuate the self in this work of representation that, according to Deleuze, cannot be considered a true act of thought (Deleuze 1994, p. 138). This, in Água Viva, would be the limitation of the author's need to think, or what also appears as the self-reflection that hinders the attempt at looking at the mirror itself:

a mirror in which I see myself is already I, only an empty mirror is what the living mirror is. Only a very delicate person can enter the empty room where there is an empty mirror, and with such lightness, with such absence of self, that her image leaves no mark. (Lispector 1973, p. 72)

The extreme experience of thought both Deleuze and Água Viva express through the mystical term "beatitude" seems paradoxically effortless; a matter of bliss, joy, and passivity (it emerges when Lispector's "author" stops trying to think, or Dickens' evil man falls into a coma). For both, accessing such beatitude paradoxically presupposes violence to the subject of representation. ${ }^{15}$ For Deleuze, the emergence of thought without an image depends on the violence of what he defines as an encounter, where a force unrelated to the cogito's "need to think" triggers thinking. ${ }^{16}$ Deleuze draws on Plato's distinction between objects of recognition and violent sensations (aisthēteon) (Deleuze 1994), and also on the thought-inducing force of Proust's articulation of love and jealousy, as opposed to the lukewarm friendship that serves as the traditional model of philosophical love (Deleuze 2000). While jealousy as an unpleasant affect suitably illustrates violence to the self-image, it remains within the register of the ego and thus inaccurate to examine the encounter's link to a life's beatitude. Lispector's fiction shows

12 "Autor," a masculine noun in Portuguese, is the reason for this pronoun in the English translation.

13 The writer adds that it could also say of "the everything" but "nothing" insofar as it is quantity it becomes limited. Lispector's beatitude shares some concerns with the Kantian problematic of the sublime, then, and, rather than pointing to a quantity inapprehensible due to its greatness, it is resolved in terms closer to the Buddhist concept of emptiness, Śünyatā, which involves empty awareness and non-self. See (Williams 1998).

14 In this essay, Deleuze describes his term as a lens for the immediacy of everything in the world that escapes the purview of the subject-object polarity. In Difference and Repetition Deleuze explains that transcendental empiricism deals not just with the conditions of possible experience but with those of real experience, where the Kantian faculties of the mind are pushed to the limit.

15 This violence is at stake in The Passion's Christian overtones, for instance, initiating an exploration of inhuman life that continues beyond that novel.

16 "Something in the world forces us to think. This something is an object not of recognition but of a fundamental encounter" (Deleuze 1994, p. 139). 
that the stakes of the encounter involve non-oppositional modes of relation that blur the ego-sustaining distinction between bodies and entities in favor of an uncanny intimacy.

\section{Sauvage, Selvagem}

In transcendental empiricism's "passage from one sensation to another," where sensations are considered "as becoming, as an increase or decrease in power (virtual quantity)" (Deleuze 2007, p. 384), Deleuze detects "something raw and powerful." While the latter translation sounds idiomatic in English, the choice of adjectives in the French sentence- "quelque chose de sauvage et de puissant" (Deleuze 2003, p. 359)—suggests more than rawness and power. Puissant implies the philosophical distinction between actuality and potentiality, which is crucial to Deleuze's discussion of the virtual (therefore not actual) nature of immanence. ${ }^{17}$ I wish to emphasize sauvage here, insofar as Deleuze's use of this word interestingly relates to the "loss of human montage" that is a condition of impersonal life. Sauvage involves, indeed, the violence to representation announced with regard to beatitude, and the word's story and presence in the work of Deleuze and Lispector brings even more to this discussion. In Deleuze's Difference and Repetition, differences are described as "sauvages ou non domptées" (Deleuze 1968, p. 71) "wild ${ }^{18}$ or untamed" by "the simplifications of limitation and opposition" (Deleuze 1994, p. 50) that enable identities. Lispector's Passion points out that the "human montage" relies on such "civilizing" operations to preserve the distinction between self and world: "The light general pleasure-which seems to have been the tone in which I live or lived-perhaps came from the world's not being either me or mine" (Lispector 1964, p. 30). Sauvage reappears in Anti-Oedipus by reference to Claude Lévi-Strauss' La Pensée sauvage and as a form of societal power different from ("civilized") capitalism (Deleuze and Guattari 1972). Lévi-Strauss' ethnological expeditions point toward societies in Lispector's Brazil called sauvage for diverse reasons. In the work translated as The Savage Mind, the ethnologist contests the Western prejudice that such societies' thought and language is less abstract, exact, or complex, to assert, instead, the undying presence of la pensée sauvage "savage thought" within so-called civilized cultures, coexisting with a "domesticated" thought. Deleuze's logic of "wild differences" swarming on beside oppositional identities is indeed aligned with what Lévi-Strauss subtly highlights, by way of a pun that recalls the etymology of sauvage, from silva, the forest or jungle: the coexistence of the European pensée sauvage (wild pansy) with domesticated garden pansy varieties.

Lispector too will take us into the strange domain of flowers, but before entering it in the present essay, one should note that Lispector does more than show that G.H.'s "wild" cockroach coexists (though far from harmoniously) with the "civilized" upper-class woman in her apartment. The order of life that disorganizes the human is disclosed for G.H. by the cockroach in a shift parallel to the one heralded in Nietzsche by the death of God. The latter, according to Deleuze, is key to accessing difference, and Jean-Clet Martin explains that it gives rise, exactly, to "a savage perspectivism" (Patton 2011, p. 24). The title of Lispector's first novel, Perto do Coração Selvagem (Near to the Wild Heart) indicates the crucial vicinity of a distinctly wild, selvagem, or sauvage center, life-organ, or site of feeling (since "heart" conveys all this) to the location of "inhuman life," and of her own writing practice. ${ }^{19}$ In Água Viva wild words form a dense jungle "densa selva de palavras" (Lispector 1973, pp. 24, 61) beyond meaning, "and something wild (selvagem), primary, and enervated rises from my swamps" (p. 38). The voice in Água Viva asks her reader whether "savages (selvagens), barbarians, decadent noblemen, and gangsters" ... mean anything to [her/him]" (p. 26), and she briefly adds, "It speaks to me"

17 The "increase or decrease of power" is also "de puissance" in the French.

18 "Sauvage" in Difference and Repetition is a translation of the English "wild" in the American mystical pluralist poet Blood, whose affirmation that "the universe is wild-game flavored as a hawk's wing" is cited by Deleuze in the latter's description of nature as perpetual bearer of difference (57).

19 After all, as she points out in an interview, Lispector's last name in Latin means "lis no peito," "lily in the breast" (in Portuguese "breast" commonly refers to the heart); it would be then a wild lily. 
(ibid.). Yet Lispector stresses the resistance at work in calling another society "savage" differently from Lévi-Strauss' observation of the "civilized" mind's contempt for allegedly unscientific mentalities. It is, rather, through a more visceral kind of shock. In The Passion, the formerly sophisticated G.H. not only kills, not only touches, but also puts the cockroach she killed in her mouth in an attempt to eat it. ${ }^{20}$ In other words, she implicitly repeats the Tupinamba ritual with the cadavers of their enemy prisoners (on which, some decades earlier, Brazilian avant-garde "cultural cannibalism" was modeled ${ }^{21}$ ). For his part, Michel de Montaigne considered just this practice in the powerful 1579 essay Des Cannibales, an extreme attempt to think from the perspective of "the savage." 22 Acknowledging this people's practice of a cannibal ritual as a fact, Montaigne boldly finds "nothing barbarous and savage in that nation, from what I have been told, except that each man calls barbarism whatever is not his own practice" (De Montaigne 1943, p. 89).

Upon embracing the sauvage gesture at its most visceral, another mode of relation is sustained, coherent with the univocity of being. Beatitude's sauvage aspect does not diminish its effortless radiance. "Feeding on the enemy's body" seems exemplary of this perspectival shift, which requires radically welcoming the enemy and facing the foreignness and hybridity of the body typically called "mine." 23 As Montaigne points out in recalling a prisoner's song: “These muscles,' he says, 'this flesh and these veins are your own, poor fools that you are. You do not recognize that the substance of your ancestors' limbs is still contained in them. Savor them well; you will find in them the taste of your own flesh'" (ibid., p. 111). ${ }^{24}$ Deleuze too, with Guattari, insists that each body "contracts" that which it comes from, and its becoming occurs by its relations to other bodies, in "unnatural participations or nuptials" (Deleuze and Guattari 1987). ${ }^{25}$ The sauvage aspect of transcendental empiricism, then, involves breaking thought and language out of the limits of its own domestic mores to confront the differential time of the event that persists alongside representation or "human montage." 26 In Lispector's cited passage on beatitude, a "form," an "author," and the latter's "need to think (an object)" would be instances of the domestic mores to renounce, privileging instead the passage of sensations that strips away the neat distinction between self and other. This uncanny freedom, encapsulated by a life, is difficult to attain or even to want to pursue in the first place.

\section{Handholding in Lifewriting}

Lispector's rare curiosity for this impersonal life is bound up with the act and time of writing. What kind of force do life and writing exert upon each other? This fundamental question presupposes a distinction and a certain tension between the two terms related by the conjunction "and," which here

20 On the function of touch in The Passion According to G.H. see (Goh 2016a).

21 Tarsila do Amaral and Oswald de Andrade brought this motif to painting and poetry. See the former's painting Abaporu (1928), which inspired the latter's Manifesto Antropofágico. Their "cultural cannibalism" proposes an assertion of a multiple and protean identity for Brazil rather than a (post-)colonial one either imitative of or reactive to European models. For a helpful, non-identitarian analysis of antropofagia in Brazilian poetry that takes Deleuze's immanentism into account, see (Shellhorse 2015).

22 One could argue that this effort exemplifies Deleuze's distinction of a forceful and violent "object of an encounter," rather than of recognition. It may seem odd, in light of Lispector's and Deleuze's search for the impersonal beyond "self," that Montaigne conceives of his essays as a self-portrait; in any case, the spirit of this self-reflection aims at critiquing processes of subjectification by questioning the cultural values available for the construction of individual identities.

23 Goh (2016b) compares the stakes of eating in The Passion and Água Viva through a different approach, where the former text involves incorporation of another and the latter implies "consuming oneself," since the narrator claims to have eaten her own placenta. Goh notes Peixoto's distinction of the latter as "nondamaging self-devouring" (Peixoto 1994) and adds that in this case nourishing the other is involved.

24 Interestingly, according to Ong, "the Tupi of Brazil would not eat a captive singer, believing that he belonged to another world" in (Zumthor 1990, p. xi).

25 The philosophers discuss immanent bodies in terms of "haecceities" here, adopting Duns Scotus' concept. While they never cite Montaigne, they offer a passage that closely echoes the tone of the singing prisoner: "For you will yield nothing to haecceities unless you realize that that is what you are, and that you are nothing but that.... You are longitude and latitude, a set of speeds and slownesses between unformed particles, a set of nonsubjectified affects. You have the individuality of a day, a season, a year, a life (regardless of its duration) ..." (p. 262, emphasis in the original).

26 Representation's first domestic more would be the self-other opposition. 
performs a connection crucial for each of the terms, since, for Lispector, neither "life" nor "writing" can function without the other. The relation to which the writing voice in The Passion and Água Viva invites her readers is one of wandering beside her rather than following. "Give me your hand": The Passion recurrently features this simple plea to the reader, addressed sometimes as meu amor "my love." The kind of reading practice Lispector proposes is thus a loving form of intimacy between strangers, ${ }^{27}$ and embracing the fiction of holding hands with the writer is what allows us to consider these two notions, life and writing, that in turn lose their clear-cut separation as we grant that they hold hands as well. ${ }^{28}$ In a subsequent request for the reader's hand, one learns that what gives rise to handholding between reader and writer is an unprecedented foray into the unknown: "Give me your hand. Because I no longer know what I'm talking about" (Lispector 1964, p. 97). This disjunction between the speaker and the meaning of her statements that emerges with the intimate conjunction of speaker and addressee is crucial for the confrontation with impersonal life, and it has important consequences for the idea of time operating in Lispector's experimental work. ${ }^{29}$ In the last novel published during her lifetime, The Hour of the Star, the narrator, a male writer named Rodrigo S.M., who struggles to begin telling the story of Macabéa, a young and poor Northeastern Brazilian woman, confesses to not knowing where the story will go and to this uncanny feeling: “It's like I'm writing in the very hour in which I am being read" (Lispector 1981, p. 12). What is this flickering hour? When?

Agora and já, both Portuguese words for "now," have a major role in both The Passion and Água Viva, and they first of all express an essential synchrony-two (who, as implied by maintenant, the French word for "now," are "main-tenant": holding hands). These two-writer and reader, narrator and character, writing-reading and its hour-undergo an encounter that neither reduces the two to one, nor merely opposes one to the other, but instead harnesses an affective tension. Two, then, introduce the shift in perspective, an in-between usually disregarded yet essential to $a$ life or to the plane of immanence. At stake is an act of defamiliarized contemplation that allows for wandering beyond the confines of identity and meaning. And only then does a subtle glimpse at "inhuman life" suddenly become available. In Água Viva the narrator describes this practice of defamiliarized contemplation, with regard to painting, the word, and life: " ... when I find painting strange, it is there that it is painting. And when I find the word strange, it is there that it attains sense. And when I find life strange, it is there that life begins" (Lispector 1973, p. 76). This statement suggests that taking such an unusual viewpoint requires calling into question one's supposed knowledge about life, painting, or writing, if not renouncing any form of mastery or external position to these movements whatsoever. Notice that while the (writing) "I" loses a sense of familiarity with the word, "it is there" that the word "attains sense" for itself, there where "I" loses it. ${ }^{30}$ Paradox, the operation in this passage and also the dominant mode in Água Viva's contemplative exercise, ${ }^{31}$ baffles reason as it strives to place writing in

27 The non-oppositional, intimate relationship between strangers Lispector repeatedly proposes is in line with the one explored by Bracha Ettinger in terms of the "matrixial borderspace," which involves the unborn child in the womb and the mother-to-be (Ettinger 2006).

28 An effect of this procedure is noticeable in a recurrence in critics' titles. Cixous' essays on Lispector translated by Verena Andermatt Conley (Cixous 1990) bear the title Reading with Clarice Lispector. Marcia Cavalcante's guest lecture at the University at Buffalo in 2017 was called "Time Being (reading with Clarice Lispector)". The preposition "with" in the title of my own essay speaks to this too.

29 For an excellent study of Nietzsche's perspectivism that refers to Deleuze's conjunctive analysis and disjunctive synthesis, see (Zupančič 2003). This section of my essay draws on this exposition of the in-between or "Two" that enable "a decentering of perspective."

30 One might hear, in this move for the word attaining its own sense, a Heideggerian overtone. "When does language speak itself as language?" asks Heidegger, introducing Stefan George's poem “The Word" (Heidegger 1971, pp. 59-60). There are many instances where Lispector and Heidegger coincide in their concerns for language, being, and mortality. However, this concern for the word's autonomy in a poetic register is more specifically an experience of the poets, as Heidegger recognized and Mallarmé announced in Crise de vers (1897): "The pure work implies the disappearance of the poet speaking, who yields the initiative to words..." (Mallarmé 2007, p. 208)

31 Água Viva evokes negative theology, where enunciation advances through a sequence of failed attempts against "something" unknown and powerful that ultimately exhausts language, having stumbled through all the contradictory statements this hidden power sets off. In Água Viva the unknown power is life, but it is not external to the writing process. For an analysis of Christian mysticism as a purely speculative, writing exercise to which no experience correlates, see (Turner 2002). 
that very difficult and imperceptible moment or site ("it is there"), a breaking point-like the crack of dawn-where "life begins" or "life is born." The "strange" factor in this beginning comes, once again, from its irreducible twofold character. Another passage from Água Viva seeking the first principles of life proposes an image akin to but distinct from that of the cannibal, of feeding from another (female) body, this time by nursing: "What is the first element? Immediately there must have been two to have the secret intimate movement from which milk gushes" (Lispector 1973, p. 28).

\section{5. "Água Viva": Naming the Unnamable}

The radical estrangement that takes place within the time of writing as portrayed in Lispector's novels is the distinctive trait of this agora or já: " ... what I had never experienced was the collision with the moment called 'now.' ('já')" (p. 78). This other sense of time, experienced as a shock, an encounter in the Deleuzian sense, is usually obscured by the sense of time of a transcendent self, which is precisely what Deleuze seeks to relinquish in favor of the field of immanence or the transcendental field as a virtual site for the event. ${ }^{32}$ In The Passion, the cockroach qua inhuman, a-chronological expression of life, an expression of o agora, the now, mobilizes this interruption of transcendence, which is considered "false": "The cockroach's much greater nature made anything ( . . ) -name or person-lose its false transcendence" (Lispector 1964, p. 96). Água Viva will subsequently locate "genuine transcendence" (Deleuze's "immanence"), however wild and unimaginable its thought may appear: "The transcendence inside me is the living and soft "it" and has the thought that an oyster has" (Lispector 1973, p. 28).

For Lispector, the act of writing constitutes a struggle to give consistency ("living and soft") to this thought that relinquishes the self's illusory external perspective on life and arrives at a "transcendence inside me," that is, an internal limit of thought that the oyster's opacity conveys. Deleuze states that "only when the world, teeming with anonymous and nomadic, impersonal and individual singularities, opens up, do we tread at last on the field of the transcendental" (Deleuze 1990, p. 103). Such a field is indeed for Lispector that of the now without transcendence, and treading on it reveals its strange texture. It is relevant in this regard to consider the symptomatic fact that Água Viva underwent at least two changes of title. "Objeto Gritante" "Crying Object," one of the manuscript's earlier titles, ${ }^{33}$ expressed Lispector's unease when trying to identify and name such an indefinite piece of writing, while describing the insistent, vital urgency that allowed it to persist and be published in spite of its oddity. The crying object remains in the published version of Água Viva, in a particularly tempestuous passage:

What am I in this instant? I am a typewriter making the dry keys echo in the dark and humid early hours. For a long time I haven't been a person. They wanted me to be an object. I'm an object. An object dirty with blood. I am an object that creates other objects and the machine creates all of us. It demands. The mechanism demands and demands my life. But I don't obey totally: if I must be an object, let it be an object that cries out (grita). There's a thing inside me that hurts. Ah how it hurts and how it cries for help (grita pedindo socorro). But tears are missing in the machine that I am. I'm an object without destiny. I am an object in whose hands? Such is my human destiny. What saves me is the cry (o grito). I protest in the name of whatever is inside the object behind the behind the thought-feeling. I am an urgent object. (Lispector 1973, p. 79)

In these dramatic lines a perplexed voice asks questions about its being, whose most immediate points of reference lie in inhabiting the instant's this-ness and in experiencing the opacity of its own existence.

32 Deleuze sustains throughout his works a distinction between two temporalities: Chronos, a striated, chronological time that corresponds with the plane of subjects and objects, and the entirely different Aiôn, a virtual, smooth, nonlinear time of the event, regulated by singularities alone.

33 This title appears on the manuscript held at the archive in Casa de Rui Barbosa in Rio de Janeiro. 
Its questions, a way of crying out, attest to "a thing inside of me that hurts" and that "cries for help," since this object has no destiny, which is to say that there is nothing written beforehand to indicate the direction or the telos of the writing. The cry itself saves this object, it states, insofar as crying is a way of deviating from the mechanical and pointless reproduction that seemingly caused its existence. It is important to note this gesture's link to the noted breaking point "where life begins," indeed, to the birthing cry and the newborn's vagitus, which appear in this passage as rebellious and liberating, insofar as the cry in writing gives life beyond the "mechanism" that tries to keep this life in its own grasp. In relation to the cry, Hélène Cixous has remarked on "the call" and its register of birth in Água Viva (Cixous 1990, pp. 39-40). Indeed, as previously noted in the image of nursing, birthing/being born and infancy in Água Viva suggest another exemplary relation between impersonal its, alongside that of the cannibal in The Passion. Its scene of life's beginning offers, furthermore, an idea of the instant's this-ness, the time Lispector calls "now."

This mode of relation has crucial consequences for the notions of writer and reader. In the previously mentioned The Hour of the Star, Rodrigo S.M., too, struggling to begin writing about poor Macabéa, stresses the role, found in the previous passage, of spokesperson crying out for an unaddressable it: "It's my duty, however artlessly, to reveal life to her. Because there is the right to the cry. So I cry out. Pure cry and without begging alms" (p. 13). We find here the very logic of the I's "protest in the name of whatever is ... behind the behind of thought-feeling" in the passage from Água Viva, whose other tentative title had been precisely Behind Thought, in whose name the entire text would be crying out. ${ }^{34}$ If, behind thought, it, like Macabéa, cannot cry or protest in the first person (Rodrigo S.M. must do so for her to expose her to life, just as he cannot do so for himself), they are no less entitled for that reason to this liberating cry of life. One might say then that a cry for and of life is at stake in this site of writing. ${ }^{35}$ It is thus suitable to find, exactly, a cry initiating both Água Viva ("Aleluia, grito eu" "Hallelujah, I cry" (Lispector 1973, p. 9) and Um Sopro de Vida (A Breath of Life) ${ }^{36}$ ("ISTO NÃO É UM LAMENTO, é um grito de ave de rapina" "This is not a lament, it is a cry of a bird of prey" (Lispector 1978, p. 13)). The latter title provides another hint to the cry's privileged status in Lispector, and it consists in the vital projection of breath it performs. The originary yes that according to Rodrigo S.M. began "everything in the world" (Lispector 1981, p. 11) is, at its most fundamental, a cry too-one accepting and joining (like hands) another breath, which being born entails, precisely, as the newborn cries out and inhales the surrounding air. ${ }^{37}$

Lispector turns writing and reading into a wild experience with the limits of language, which the cry, like the wordless infant, manifests. This, exactly, is the fundamental scene, "behind the behind-thought": "Behind thought—even further behind it—is the ceiling I looked at when I was an infant. Suddenly I was crying (chorava)" (Lispector 1973, p. 39). While only accessible through language, life begins only by writing at the extreme point of language's necessary failure, as Lispector's narrators are aware and confess to their readers. For instance, in the following passage from Água Viva, the voice confesses to its addressed "you" that it does not know how to write; the consequence of this for the reader is encountering something that therefore cannot quite be a genuine book:

I write to you this facsimile of a book, the book of someone who does not know how to write: but it's that, in the subtlest domain of speech, I almost don't know how to speak. (Lispector 1973, p. 50)

34 The full title was Behind Thought: Monologue with Life. Its second half is a paradox that seems to mark the intense silence of the life to which the voice speaks-cries, but also that both the monos and the logos are undermined by life and by with, which open up the breathing space of a togetherness in alterity at thecore of this voice's speech.

35 For an analysis of the "screaming object" in Água viva that interrogates the work's close connection to Lispector's newspaper chronicles and the problem of impersonal and intimately personal life, see (Friis 2016).

36 Written at the same time as The Hour of the Star, this work was published posthumously.

37 A Breath of Life reflects on the beauty of mouth-to-mouth resuscitation as an instance of shared, lifegiving breath. 
This subtlest domain of speech, where knowledge and eloquence fail, not only spoils the possibility of a "genuine book" (which according to the logic in the cited phrase ought to be the product of firmly pre-established knowledge); it also must lie very close to the strangeness "where life begins," insofar as, the text states in a later passage, "life is unpronounceable" (p. 72). For his part, the male author struggling to begin Um Sopro de Vida (A Breath of Life) declares his intent to "understand that lack of definition of life (da vida)" (Lispector 1978, p. 19) as he immediately adds, while subtracting the definite article from vida: "Vida não tem adjetivo" "Life has no adjective." All of these instances emphasize the fact that there is no word in language or criterion to accurately grasp life in its full neutrality. Alenka Zupančič's explication of Nietzsche's concept of life speaks to this very problem: "The power of Being is neutral, impersonal, anonymous, and indiscernible. The name 'life' corresponds to all these non-properties together. 'Life' designates the integral equality of Being"' (Zupančič 2003, p. 88).

To consider writing and life as readers with Lispector is to plunge into an extreme experience at the cost of breaking out of good sense and grammaticality. It also calls for a strange, neither active nor simply passive position. Already toward the end of The Passion, "inhuman life" obliges G.H. to contort language in an impossible formulation: "a vida se me é" (Lispector 1964, p. 179). It is also impossible to accurately translate this. A vida "life," is the phrase's subject, but its subsequent pronouns, se and me, introduce a complex problem. Se refers back to the subject and assigns it a reflexive action, while me, an ethical dative, indicates a peculiar receptivity of the speaker. The sentence emphasizes life's effect upon the speaker, where the latter is subtly entangled with the actions of life as subject. The conjugated verb "to be," $e$, at the end of this phrase has a strange effect, since it is not simply that "life is," and not even that "life is me," but that "life is itself to/on me," where the non-copulative "is" slightly alters this "me." 38 "Is" comes unhinged from its usual linking function to become an action verb. G.H. in the statement becomes a receptacle of being as a specific, dynamic, and intensive affect, perhaps approachable as the unnamed "something inside me that hurts," but which may also emerge as joy, as in the cited cry of hallelujah. Either way, the unidiomatic sentence "a vida se me é" conveys the effects of confronting life for G.H., who is well aware that she writes her account beyond an acceptable use of language.

Life and writing as explored in Lispector's texts occupy, then, a shared realm that poses the greatest challenge to speech and the use of words. While language initially appears as the constraint through which human life may not only be, sometimes, examined, but also carved out, writing places an even more specific constraint on the experience of life, a creative constraint that stresses life's unknown and undetermined character (hence Lispector's insistence on a "lack of destiny"), and that seeks an interaction without a program or even outside the program of making sense (which the cry, as utterance beyond meaning, also expresses). ${ }^{39}$ The constraint's tension yields in this way a certain freedom, a wandering movement of two.

Hence, the definitive title Água Viva is anything but defining. It may be literally translated as "living water," and also alludes to the high ocean tide under the moon's influence, known as águas vivas. Furthermore, while in the text itself it is the oyster that punctuates a formless, neuter opacity, água viva names an even more ungraspable mollusk, a species of jellyfish. ${ }^{40}$ Thus, if one certainly notices

38 Idra Novey translates it as "Life just is for me" (Lispector 2014, p. 189). Novey reflects on the extreme experience of translating The Passion (pp. 191-93).

39 The cry involves a vocal gesture of overstepping the confines of sense to which the word in its habitual function limits speech. Jacques Lacan's Borromean knot in which he discerns the field of "sense," between the symbolic and the imaginary registers, importantly notes that this field wards off the real and, as Néstor Braunstein suggests, it is the field of ideology "as an area of agreement on reality and occupies the territory of meaning insofar as it is horrified of the real" (Braunstein 2006, p. 109).

40 Lispector's chronicles from 1967 to 1973 feature different versions of several passages from Água Viva before the latter was published. "A geleia viva como placenta" "The living jellyfish like placenta" (29 January 1972) strikingly relates a dream in which the author sees a "living jellyfish" on her table (the chronicle uses "geleia," a synonym of "água viva"), reflecting her own face, deformed. She relates the drama of not being able to touch it painlessly, parallel to the unbearable "essential deformation" of her own image, which reveals a ubiquitous "primary life" from which not even death is spared (Lispector 1999, pp. 402-3). 
an aqueous vitality in all instances, its manifestations differ widely. The choice of such a polysemous title clearly emphasizes water's presence in diverse and discrete life forms, and even across organic and inorganic planes; it seems to pronounce and, indeed, privilege a fluid, transversal viewpoint that cuts across discrete forms and phenomena, as though assenting to Thales of Miletus' proposition of water or Anaximander's apeiron, the limitless, as the underlying element of reality (and as noted earlier, the vital gush of milk suggests it must have always been two). This might explain the decision to leave the original title in the English translation. The title's first English translation, The Stream of Life, only alludes to water figuratively but remains interesting in light of transcendental empiricism since it invokes William James' stream of consciousness, which in turn informs Deleuze's description of "the passage from one sensation to another" (Deleuze 2007, p. 384) or the flux of consciousness at infinite speed that defines the virtual field of the transcendental or immanent thought without a subject-the very procedure I highlight here in Lispector. ${ }^{41}$

If the title Água Viva expresses the movement of writing in its relation to life according to Lispector, it shows that writing devotes itself to accounting for the experience of being moved by and coming intimately close to an impersonal, anonymous life; the text is, in fact, nothing but that experience. Reading this writing thus entails entering the strange temporality that fuels writing without a definitive shape.

\section{Writing out of Bounds}

The first and last phrases of Água Viva—“É com uma alegria tão profunda" "It is with such profound joy" (Lispector 1973, p. 9) and "O que te escrevo continua e estou enfeitiçada" "What I am writing to you goes on and I am entranced" (Lispector 1973, p. 87)—deliberately undo the sense of a beginning and an ending. Instead, the first phrase, which does not explain what "is" (with such joy), presupposes an earlier one that is simply not legible, while the latter affirmation contradicts its own status as the final phrase available to readers. Thus, these two brief phrases unfasten the edges that would give the book its form and format as such, allowing it to overflow. These moments in the text confirm the previously cited confession that this is not a genuine book, since books hold together with beginnings and endings, to say nothing of front and back covers.

A voice speaking in the first person, the only constant, calls into question its writing action and relationship to words, while calling out to a second-person reader in an intimate, affectionate tone (like G.H. in The Passion) and affirming an unspeakable desire, in a variety of formulations that begin with "quero" "I want." The enounced desire must be closely involved with what the text insistently invokes both with words within the lexical field of vida "life" and it. A concise definition of living that includes both terms is offered toward the end of the text: "Living is this: the joy of the $i t$ " (p. 85). As for "joy" (alegria) it is also a highly specific term for Lispector, designating something beyond the scope of any conventional, socialized feeling, even if this affect is proposed as intrinsic to the act of living, a property of any and every kind of $i t$, and therefore not exclusive to "the author" nor to any other I. Interestingly and paradoxically, when the pronoun it in the statement "living is the joy of the $i t$ " is read as a possessive genitive, it subverts any kind of property, since it presents in this text a neuter that defies appropriation. ${ }^{42}$ Joy and desire in Lispector indeed stand close to their Spinozian account, in which joy increases desire (and in this regard too Lispector and Deleuze meet). Let us recall that for

41 It is relevant to note that the first translation into English of Água Viva was published by Minnesota University Press, in an academic, lively "French theory" context, whereas Lispector's context in Brazil was not academic. The reception of "Clarice," as she is referred to in Brazil, is wide and warm, and she is often considered as Brazil's greatest novelist. The newer translations of her works have appeared in Penguin Modern Classics, a categorization that makes it possible for a broader English-speaking audience to see the dimension and nature of her contribution on the same level as Joyce, Kafka, Proust, or Beckett.

42 In The Passion the cockroach figures, as mentioned, this very radical neutrality and also impropriety, an it form of life that is impossible to appropriate, incorporate, or assimilate, even if this is attempted by the woman, in a struggle against her nausea to commune with this creature. 
Spinoza, this desire is desire "to persist in being," whereby he points us back to the verb that begins Água Viva in the third person, é, it is, suitably accompanied by joy ("é com uma alegria ... "). To persist in being or to go on living in this impersonal plane is an act of joy, as the voice in Água Viva declares, even at the brink of falling silent or dying out.

Perspective, form, and eloquence-rhetorical elements indispensable for establishing a firm footing and securing communicability-are continually disrupted by the very passion for life and living that fuels the writing voice's flow of phrases. ${ }^{43}$ If the text is willing to take this risk, it is because what is at stake is not even life according to the writer, which would imply her own standpoint and a certain rhetoric and frame or delimited horizon, but, rather, a vida vista pela vida "life seen by life." At times in Água Viva the writing voice is able to assert this perspective: "Ésta é a vida vista pela vida" (p. 13) "This is life seen by life." Life seen by life as a perspective would be, given the previously examined passages from this text, that moment or point at which life begins, where the writing-reading "I" becomes estranged from it. As soon as this perspective is gained, the writing voice notices that it is brushing the limits of making sense, even as she grants freedom to such a puzzling affirmation. It is therefore followed by: "I might not make sense but it is the same as the pulsing vein's lack of sense" (ibid.). The pulsing vein lacks meaning, makes no sense, without ceasing to pulse, that is, to mark a vital rhythm, just as the writer's words may make no sense, but continue pulsing on as well. To write for Lispector is to attend to this very pulsation that escapes and perhaps precedes meaning, in a gesture closely attuned to the initially discussed beatitude and to which we now turn. ${ }^{4}$

\section{Feminine}

A few lines later, the affirmation of life's viewpoint on itself returns, preceded by an echoing sim, yes, and followed by a reflection on the effects of such an encounter upon writing:

Yes. This is life seen by life. But suddenly I forget how to catch (captar) whatever is happening, I don't know how to catch whatever exists except by living here each thing that arises and no matter what it is (e não importa o que): I am almost free of my errors. I let the free horse run fiery. I, who trot nervously and only reality delimits me. (p. 18)

The writer's task is to "captar," to seize and receive what happens, what exists, and the process of living is what at once enables and delimits this activity, which again emerges in tension with the act of free and indiscriminate receptivity that life's viewpoint requires. The horse (as writing) freely gallops while she, the writer, only trots nervously as she goes about, "vivendo aqui," that is, here, constrained by reality, and in the process of living through or enduring whatever may emerge. Lispector's writing confronts the rigor of life's own impossible perspective while remaining modestly aware of the limitations of the writer's condition as a speaking being, speaking in this case Portuguese, a language that, furthermore, constantly demands a gender position and inflects her trotting not just with nervousness, but also with a feminine ending in the adjective "nervosa," which in addition to qualifying her, opposes her to the masculine "fogoso," attributed to the running of the horse (cavalo, a masculine noun). The consecutive sentences seem to emphasize that nervosa almost rhymes with fogoso, but the symmetry fails by a vowel. Certainly, the project of writing life involves, at times, overstepping these delimitations, especially when it is a matter of getting as close to the perspective of life itself as possible, and the strategies of transgressing fundamental limits and undoing boundaries and form underpin the attempt at bringing writing to confront life as such that Água Viva undertakes. Yet these transgressions never amount to a mere indifference to or denial of the determinations of a language, here apparent in terms of gender. Whereas "the author" in A Breath and Rodrigo S.M.

43 See (Fitz 2001) for a post-structuralist analysis of the interplay between indeterminate meaning and desire in Lispector's oeuvre.

44 The subtitle of Um Sopro de Vida is indeed Pulsações, "pulsations." 
in The Hour are male and write in the masculine, ${ }^{45}$ the voice writing in Água Viva is inflected in the feminine not just in the cited passage but throughout the entire text. The latter work's point is not, of course, to establish a feminine identity, since approaching life involves a profound undermining of identity, and femininity is crucial in mobilizing this operation. The feminine in the Portuguese language is thus engaged as a creative constraint for writing that exposes the limit of sexual difference to which speaking beings are held, and that the standard masculine inflection, used in the abstract and whenever at least one male element features in a verbal construction, occludes. Água Viva thus suggests that only by obviating the determinations of sexual difference can there be a genuine effort to attain a truly impersonal it. The feminine inflection in Água Viva is closely linked to its insistence on the limits and failures of language to pronounce, define, or name life and living. One might say it punctuates this failure and bears witness to the "lack of meaning" noted in the first instance of "life seen by life," bringing writer and reader close to something outside meaning and sense that nonetheless insists, like a pulsing vein, or like a cry of joy or pain beyond signification and socialized feelings. ${ }^{46}$

Like G.H., who loses her "false transcendence" and identity as a woman after the encounter with the neuter and inassimilable cockroach ("the horror of neutral life that lives and moves" (Lispector 1964, p. 92)), Água Viva's feminine $I$ is no support for a transcendent self. Instead she becomes the bearer of the it "behind thought," and it is this commitment that enables in the text her attention to non-human life, and consequently also the reader's. Earlier in this essay I considered Deleuze's claim that there was something "sauvage" about impersonal life, about this it and its approach, by associating this logic with Lévi-Strauss' "wild pansy" as a figure of "savage thought." Perhaps the latter is more than a pun, and flowers, as a case of inhuman life, bear an important lesson concerned with sexual difference and the neuter. If G.H. devotes her writing to the humble, wordless cockroach, the I in Água Viva writes and paints a flower catalogue she calls "de natura florum" (Lispector 1973, p. 55). If G.H. asks for the reader's hand, Água Viva's I asks us to pay attention to the order of flowers with her: "pay attention and as a favor: I am inviting you to move to a new kingdom" (p. 52). Under this mode of attention it becomes possible to notice that a rose is "feminine" and while "its perfume is a mad mystery," a rose is no longer it, but instead already a "she" (ibid.), and not just grammatically, but also aesthetically, as a matter of style: "her way of blooming into woman is beautiful" (ibid.). The sunflower instead seems "masculine" to the writer (p. 53). Of the violet: "its almost-not-perfume is a smothered glory but demands that people seek it. It never shouts (grita) its perfume. Violet says levities (levezas) that cannot be said" (ibid.). The I's attention floats across different flower species and onto bees and ants, who, she notes, are also she and not it (p. 56). To recall the Spinozian approach at stake in Água Viva, the style to which the I pays close attention, allowing her to detect sexual difference in these life forms, expresses their joy of being ("The chrysanthemum is of profound joy" (é de alegria profunda) (p. 56), even if it can also be spoken of as the "suffering of flowers" (dolência das flores) (p. 51) ${ }^{47}$ It is, ultimately, the intensity giving each flower its mode of life (and the chrysanthemum "shaggily controls its own savagery" (selvageria) (p. 55).

Perhaps, then, it is unsurprising that Jacques Lacan invoked the image of "the lily of the fields" from Matthew 6:28 in speculating on feminine jouissance, one not entirely rooted in language: "It is true that we can well imagine the lily in the fields as a body entirely given over to jouissance-each stage of its growth identical to a formless sensation. The plant's jouissance. Nothing in any case makes it possible to escape it. It is perhaps infinitely painful to be a plant. Well, nobody amuses themselves by dreaming about this, except me" (Lacan 2007, p. 77, tr. mod.). It seems that Lacan

45 They write about a female character, and in A Breath, that character, Angela Pralini, becomes a co-writer. On the problem of writing the feminine in A Hora da Estrela, see Chapter 1 in Shellhorse (2017).

46 This can be conceived in terms of what Lacan calls feminine jouissance, insofar as it is outside "meaning" and existence, yet it insists.

47 We find here again the possibilities of joy and pain as not mutually exclusive. Elsewhere she states that pain can be transformed into pleasure "basta um clic" "a 'click' is enough." (p. 40) 
was not alone after all, in his concern for an unspeakable joy to which the feminine lies close, even if Lispector was not necessarily "amusing herself," not in any trivial sense anyway, by "dreaming of the suffering of plants," flowers, insects, or mollusks. Água Viva's I explains her activity as an intense, constant caring contemplation: "tomo conta do mundo" "I look after the world" (Lispector 1973, p. 55). Her contemplation, which involves a purposeless looking, writing, painting of each living thing and moment, and inviting her reader to join her, is close to Deleuze's particular take on the Biblical lily of the fields. For Deleuze, the significance of "the lily and the flowers singing the glory of God" (Deleuze 1987) lies in this act's being itself a contemplation, according to its own unique "feeling" or affect, of the different elements composing each thing. If the lily "contemplates" the glory of God and God is infinity, it is because the lily can only be itself by contemplating or "contracting" this infinity, and Deleuze, following Plotinus and Whitehead, states that this operation itself is "self-enjoyment." 48 Deleuze in this way returns to Spinozian joy, and perhaps in this particular way one can understand both Lacan's and Água Viva's contemplation of flowers as a mode of "amusement," that is, as an enjoyment at contracting the joy of another living form, flower or verse. In Água Viva the feminine is fundamental in enabling this contemplation, contraction, or in the terms of Água Viva "tomar conta" (caring for) and "captar" (catching/receiving) ${ }^{49}$ Let us consider these operations once more to conclude, recalling the fact that Água Viva wants to reach it-life, even before "he" and "she" come to mark creatures and words.

\section{Natal}

Deleuze's distinction between the thought of representation, which looks at things in terms of opposition and identity, and "thought without image," which offers a glimpse at "wild" differential singularities, is concerned with the latter not "always already captured within individuals and persons," but instead as independent, as a third possibility that escapes "the undifferentiated abyss" that is usually seen as the alternative to singularities within formed individuals. This is the transcendental proper, and its aim is "giving birth in thought to the act of thinking" (Deleuze 1994, p. 139), even if this rarely occurs. A birthing act, or event, is exactly what writing "as though in the very hour of being read" undertakes in Água Viva. Thinking for Lispector takes place through writing and reading as related processes of the order of birthing/being born, which require that peculiar attitude we previously discerned, in The Passion's strange use of the ethical dative and the objectless use of the verb to be, which Água Viva designates as "tomar conta do mundo" ("to care for the world") and "captar." We have seen this verb twice in the earlier cited passage on "life seen by life," and we considered it as a description of writing's act of "catching," receiving, and inscribing whatever happens, life. While in English this verb is translated as "to capture," the gesture in Lispector's work emphasizes receptivity and attunement. ${ }^{50}$ Lifewriting here is receiving, in the way a signal is received by antennae. Lispector's operations seem to expand Deleuze's proposed third possibility, by emphasizing the need for the other that "birth" involves, to access the transcendental, in-between individuals and objects. What is received, the signal outside that lights up the receiver, consists in the germination of instants and all they carry.

48 In his seminar lecture Deleuze uses both "feeling" and "self-enjoyment" in English; he is explaining the concept of the event in Whitehead and relating it to the baroque and to Leibniz. He adds that "self-enjoyment" is "properly English" and he translates it back to French as "réjouissez-vous," "rejoice," evoking "Rejoice Greatly" from Handel's baroque oratorio Messiah, and omitting the reference to Hugo, who wrote "Le lys s'épanouit pour la gloire de Dieu" "The lily of the fields blooms for the glory of God" in the poem "Sagesse." See (Deleuze 1987). What would Deleuze think of the "tajá" at the end of Água Viva's de natura florum, a plant from the Amazon whose peculiarity, according to the text, is that the indigenous people attribute to it the power, not of song, but of eventually "saying a word" (Lispector 1973, p. 53)?

49 There is remarkable consonance between the ethics Lispector conveys through these notions and Ettinger's concept of "carriance." On the latter, see (Ettinger 2016).

50 The second paragraph of Água Viva admits to the impossible impulse to capture, featuring the verb capturar "to capture": "And I want to capture the present which by its own nature is forbidden to me: the present flees me, actuality escapes me, actuality am I always in the now (no já)" (Lispector 1973, p. 9). 
Thus, a point of access into the perspective of "life seen by life," or a kind of angle to get writing to "captar o que acontece," to "catch" and inscribe undefinable life remains unavoidable, and this angle is natal. ${ }^{51}$ The previously mentioned insistence on agora "now," or "o instante-já" "the instant-now" (especially in The Passion and in Água Viva) stresses the radically unpredictable nature of each new instant it attempts to jot down. It recalls that, while this natal dimension is constantly overlooked, its relevance cannot be simply relegated to a mythical past. Rather, it inhabits each and every instant; it is the stuff of the event. A sprouting or spawning of "cada coisa que surgir" "each thing that might emerge" becomes perceptible in Agua Viva's precosmic birthing process, ${ }^{52}$ in which the writing voice is both born and gives birth: "I am having the real birth of it. I feel faint likes someone about to be born" (p. 32). At a certain point Água Viva's writer indeed enters into the process of being born, in sequences of minimalist lines. First is increasing darkness, with the plea: "You who read me, help me to be born" (p. 33). Then comes light:

\author{
Now the shadows are retreating. \\ I was born. \\ Pause.
}

Marvelous scandal: I am born. (p. 34)

Coming into life, figured as a gradual dissipation of shadows, takes place "now," in the time of reading and in the temporality of these brief spurts of words and spacings. From "now," the text shifts to the past tense to state the fact of its birth and the flow into another moment, whose work of pausing it foregrounds for the reader by turning it into a sentence with the single word "pause." The pause gives the reader time to regard birth's "marvelous scandal," the fact that the condition of living and of any appearance entails an unthinkable passage from the shadows to the light.

The shift toward "giving birth in thought to the act of thinking" for Deleuze begins by understanding the $I$ as fractured by "the pure and empty form of time" (Deleuze 1994, p. 86), differing from itself. This very position allows Água Viva's I to write birth in these pages, where the movements become those of the world's and time's birth as well: "I hear the hollow boom of time. It's the world's deafly forming" (Lispector 1973, p. 34). ${ }^{53}$ The I's own writing, which here consists in hearing, becomes cosmogonic: "What I am writing is the music of the air. The formation of the world. Slowly what will be approaches. What will be now is" (ibid.). Writing and reading take place in the gerund, in a process of captar before the world is completely formed once and for all, and the sound of this process is also that of the hollow boom of time and the music of space ("the air"), which indicates its tempo ("slowly"). The shift from future to present ("what will be now is") emphasizes, again, the unthinkable passage into life. This "decentering of perspective," ${ }^{\prime \prime}$ from a time subjected to movement that yields persons and objects to the autonomous time of the event and of singularities, thus gives rise to Água $V i v a$ 's nonlinear flow across future, past, and present, while interweaving being born, giving birth, writing, and the world. This work brings writing and reading close to the plane of $i t:$ "My eyes are shut. I am pure unconsciousness. They already cut the umbilical cord: I am unbound (estou solta) in the universe. I don't think but I feel the it" (p. 34). The voice born here has come detached from its mother, yet being "unbound in the universe" in an unthinking state of feeling the it implies a confluence with the universe, as it is not yet an entity identified by its separation from everything else (like the

51 "Natality" in feminist philosophy underscores the universal fact (more specific than mortality) that we were all born from a woman. Lispector's Água Viva highlights this with a view to accessing the temporality of "now." See the discussion on natality in feminist philosophy: (Cavarero 1995; Diprose and Ziarek 2013; Jantzen 1999; Martin 2002).

52 For a Deleuzian, feminist theology emphasizing beginnings and unending creation with points of convergence with Lispector, see (Keller 2007).

53 The Portuguese phrases play with assonance in $o$, the hollow letter, where time resonates: "Ouço o ribombo oco do tempo. É o mundo surdamente se formando."

54 Deleuze discusses Nietzsche's idea of the eternal return as made up of decentered centers (Deleuze 1994, p. 128), which he locates at the extreme end of the straight line of empty time that fractures the $I$. 
previously considered transversal effect of the locution água viva—at once the ocean tide under the full moon and the jellyfish swimming in it).

More musical than rational, the process of writing life in this natal manner makes the I notice the it's rhythmic pulsing, evocative of childbirth:

I am pure it that was pulsing rhythmically. But I can feel that soon I will be ready to talk in/about (falar em $)^{55}$ he or she. I'm not promising you a story here. But there's it. Bearable? It is soft and is oyster and is placenta. I am not joking for I am not a synonym: I am the name itself. There's a line of steel cutting across all this I am writing to you. There is the future. That is this very day. (p. 35).

Whereas, in Deleuze's Difference and Repetition, the dissolved me and the fractured I as "empty form of time" constitutes the most extreme point of the self's unbinding, Água Viva in this passage instead discerns a rhythmic and fleshy it in the vicinity of sexual difference. Here "soft," "oyster," and "placenta" are the quasi-formless textures of rhythmically pulsing time. Elsewhere in the text we read, "It is pure element. It is material of the instant of time" (p. 32); not just time, not just the instant, but material of the instant of time, defying all measure and form. If writing will suffer the cut of sexual difference, such that $I$ admits, as above, that it will speak "in/about he or she," the enduring, almost unbearably close presence of it will keep the flow of writing within the impersonal time of the event, rather than in a narrative one (and so does speaking "in she," as the previous section of this essay shows).

From a natal angle, the act of writing becomes an improvisation telling the instants (and not a story):

I know what I am doing here: I am telling/counting the instants that drip and are thick with blood. I know what I am doing here: I am improvising. But what's wrong with that? Improvising as in jazz they improvise music, jazz in fury, improvising in front of the crowd. (p. 21)

To narrate the instants themselves is to pick them out still dripping with blood, since they are so new, and raw, just torn off the vast flesh of life. Improvising involves not only the unpredictable, but also a specifically "savage," unrefined, and unmediated contact. If this improvisation takes place "live," in front of the crowd or the reader, then the latter too must be exposed to the dripping, bloody instants. After all, this is precisely "writing in the very hour of being read," and vice versa. The passage emphasizes the peculiar engagement with time required by its movement of "jazz in fury"; the juxtaposition of this account with the previous passage on birth reveals the "furious" movement's simultaneously delicate character, since improvising requires listening ("to the hollow boom of time"). Once more beatitude and selvagem meet. As for the reader involved in this improvisation, a subtle movement, like birth's and the ethical dative's, is also called for: "Catch (capta) that other thing that I truly speak of because I myself cannot. Read the energy that is in my silence" (Lispector 1973, p. 28). As another crucial mode of captar, reading must try to remain in the time and pulse of it, where vibrant silence becomes a field for impersonal life: "My voice falls into the abyss of your silence. You read me in silence. But in this unlimited silent field I unfurl my wings, free to live" (p. 49). Reading participates thus in the wild beatitude that sustains a life.

Conflicts of Interest: The author declares no conflict of interest.

55 "Falar em" means "to talk about." 


\section{References}

Beaubatie, Yannick. 2000. Tombeau De Gilles Deleuze. Tulle: Mille sources.

Braunstein, Néstor. 2006. El Goce: Un concepto lacaniano. Buenos Aires: Siglo XXI Editores Argentina.

Cavarero, Adriana. 1995. In Spite of Plato: A Feminist Rewriting of Ancient Philosophy. New York: Routledge.

Cixous, Hélène. 1989. L'heure de Clarice Lispector; précédé de, Vivre L'orange. Paris: Des Femmes.

Cixous, Hélène. 1990. Reading with Clarice Lispector. Translated by Verena Andermatt Conley. Minneapolis: University of Minnesota Press.

De Montaigne, Michel. 1943. Selected Essays and Other Writings. Translated by Donald Murdoch Frame. New York: Pub, for the Classics Club by W. J. Black.

Deleuze, Gilles. 1968. Différence et répétition. Paris: Presses Universitaires de France.

Deleuze, Gilles. 1987. Cours Vincennes-St. Denis: Crible Et Infini 17/03/1987. Les cours de Gilles Deleuze. Available online: https:/ / www.webdeleuze.com/textes/142 (accessed on 28 February 2018).

Deleuze, Gilles. 1990. The Logic of Sense. New York: Columbia University Press.

Deleuze, Gilles. 1994. Difference and Repetition. London, England and New York: Continuum.

Deleuze, Gilles. 1997. Essays Critical and Clinical. Minneapolis: University of Minnesota Press.

Deleuze, Gilles. 2000. Proust and Signs. Minneapolis: University of Minnesota Press.

Deleuze, Gilles. 2003. Deux Régimes de Fous et Autres Textes (1975-1995). Edited by David Lapoujade. Paris: Les Éditions de Minuit.

Deleuze, Gilles. 2007. Two Regimes of Madness: Texts and Interviews 1975-1995. Cambridge and London: Semiotext(e).

Deleuze, Gilles, and Félix Guattari. 1972. L'Anti-CEdipe. Capitalisme Et Schizophrénie 1. Paris: Les Éditions de Minuit.

Deleuze, Gilles, and Félix Guattari. 1987. A Thousand Plateaus: Capitalism and Schizophrenia 2. Minneapolis: University of Minnesota Press.

Diprose, Rosalyn, and Ewa Plonowska Ziarek. 2013. Time for Beginners: Natality, Biopolitics, and Political Theology. philoSOPHIA 3: 107-20.

Ettinger, Bracha L. 2006. The Matrixial Borderspace. Minneapolis: University of Minnesota Press.

Ettinger, Bracha L. 2016. Laius Complex and Shocks of Maternality: With Franz Kafka and Sylvia Plath. In Interdisciplinary Handbook of Trauma and Culture. Basel: Springer International Publishing.

Fitz, Earl E. 2001. Sexuality and Being in the Poststructuralist Universe of Clarice Lispector: The Différance of Desire. Texas Pan American Series; Austin: University of Texas Press.

Friis, Elisabeth. 2016. In My Core I Have the Strange Impression that I don't Belong to the Human Species: Clarice Lispector's Agua Viva as Life Writing? In Narrating Life: Experiments with Human and Animal Bodies in Literature, Science, and Art. Edited by Stefan Herbrechter and Elisabeth Friis. Leiden: Brill/Rodopi.

Goh, Irving. 2016a. Le Toucher, Le Cafard, or, on Touching-The Cockroach in Clarice Lispector's Passion According to G.H. MLN 131: 461-80. [CrossRef]

Goh, Irving. 2016b. Writing, Touching, and Eating in Clarice Lispector: Água Viva and a Breath of Life. MLN 131: 1347-69. [CrossRef]

Heidegger, Martin. 1971. On the Way to Language. New York: Harper \& Row.

Jantzen, Grace M. 1999. Becoming Divine: Towards a Feminist Philosophy of Religion. Bloomington: Indiana University Press.

Jiménez Quenguan, Myriam. 2009. Clarice Lispector y María Zambrano: El Pensamiento Poético de la Creación. Madrid: Horas y Horas.

Keller, Catherine. 2007. Face of the Deep: A Theology of Becoming. London and New York: Routledge.

Lacan, Jacques. 2007. The Other Side of Psychoanalysis, the Seminar of Jacques Lacan. New York: Norton.

Lispector, Clarice. 1963. Perto Do Coração Selvagem: Romance, 2nd ed. Edição Popular. São Paulo: Livraria Francisco Alves. First published 1944.

Lispector, Clarice. 1964. A Paixão Segundo G.H.. Rio de Janeiro: Editora Rocco.

Lispector, Clarice. 1969. Uma Aprendizagem; Ou, O Livro Dos Prazeres, Romance. Rio de Janeiro: Sabiá.

Lispector, Clarice. 1973. Agua Viva; Fiç̧ão. Rio de Janeiro: Editora Artenova.

Lispector, Clarice. 1978. Um Sopro De Vida: Pulsações, 3rd ed. Rio de Janeiro: Editora Nova Fronteira.

Lispector, Clarice. 1981. A Hora Da Estrela, 6th ed. Rio de Janeiro: Livraria J. Olympio Editora.

Lispector, Clarice. 1999. A descoberta do mundo. Rio de Janeiro: Rocco.

Lispector, Clarice. 2011. The Hour of the Star. Translated by Benjamin Moser. New York: New Directions. 
Lispector, Clarice. 2014. The Passion According to G.H. Translated by Idra Novey. New York and London: Penguin Modern Classics.

Mallarmé, Stéphane. 2007. Divagations: The Author's 1897 Arrangement; Together with "Autobiography" and "Music and Letters". Translated by Barbara Johnson. Cambridge: Belknap Press of Harvard University Press.

Martin, Alison. 2002. Report on 'Natality' in Arendt, Cavarero and Irigaray. Paragraph 25: 32-53. [CrossRef]

Osaki, Harumi. 2008. Killing Oneself, Killing the Father: On Deleuze's Suicide in Comparison with Blanchot's Notion of Death. Literature and Theology 22: 88-101. [CrossRef]

Patton, Paul. 2011. Deleuze: A Critical Reader. Oxford: Blackwell Publishers.

Peixoto, Marta. 1994. Passionate Fictions: Gender, Narrative, and Violence in Clarice Lispector. Minneapolis: University of Minnesota Press.

Shellhorse, Adam Joseph. 2015. Subversions of the Sensible: The Poetics of Antropofagia in Brazilian Concrete Poetry. Revista Hispánica Moderna 68: 165-90. [CrossRef]

Shellhorse, Adam Joseph. 2017. Figurations of Immanence: Writing the Subaltern and the Feminine in Clarice Lispector. In Anti-Literature: The Politics and Limits of Representation in Modern Brazil and Argentina. Pittsburgh: University of Pittsburgh Press.

Turner, Denys. 2002. The Darkness of God: Negativity in Christian Mysticism. Cambridge: Cambridge Univ. Press.

Veloso, Caetano. 2014. Introduction. In Clarice Lispector, The Passion According to G.H. New York and London: Penguin Modern Classics.

Williams, Paul. 1998. Buddhist Concept of Emptiness. In Routledge Encyclopedia of Philosophy. Edited by Edward Craig. London and New York: Routledge. [CrossRef]

Zumthor, Paul. 1990. Oral Poetry: An Introduction, Theory and History of Literature. Minneapolis: University of Minnesota Press.

Zupančič, Alenka. 2003. The Shortest Shadow: Nietzsche's Philosophy of the Two, Short Circuits. Cambridge: MIT Press.

(C) 2018 by the author. Licensee MDPI, Basel, Switzerland. This article is an open access article distributed under the terms and conditions of the Creative Commons Attribution (CC BY) license (http:/ / creativecommons.org/licenses/by/4.0/). 